\title{
PERENCANAAN PERSEDIAAN BAHAN BAKU DENGAN METODE MATERIAL REQUIREMENT PLANNING (MRP) PADA PROSES PRODUKSI BAK MOBIL TRUK DI CV. LURSA ABADI KOTA PADANG
}

\author{
Tri Ernita ${ }^{1)}$, Riko Ervil $^{2)}$, Restiani Meidy ${ }^{3)}$ \\ Program Studi Teknik Industri, Sekolah Tinggi Teknologi Industri Padang \\ email: triernita@yahoo.co.id
}

\begin{abstract}
Abstrak
Abstrak : CV. Lursa Abadi merupakan suatu perusahaan yang memproduksi bak mobil truk. Permasalahan yang terjadi pada CV. Lursa Abadi adalah terbatasnya persediaan bahan baku yang terjadi dikarenakan tidak memiliki gudang penyimpanan, sehingga perusahaan ini harus memesan bahan baku terlebih dahulu kepada supplier dan pemesanannya masih dilakukan secara manual yang dapat menyebabkan waktu proses produksi menjadi terhambat. Oleh karena itu penelitian ini akan dilakukan perencanaan persediaan bahan baku dengan metode material planning pada proses produksinya. Tujuan penelitian ini adalah untuk mengetahui perencanaan kebutuhan bahan baku dalam proses produksi pembuatan bak mobil truk dan untuk mengetahui waktu perusahaan dapat melakukan safety stock untuk kelancaran proses produksi. Hasil dari penelitian ini menunjukkan bahwa perhitungan peramalan persediaan menggunakan metode terpilih yaitu metode linear dengan nilai SEE terkecil sebesar 0,662 dengan total rencana produksi pada periode ke 13 adalah 7 unit. Setelah melakukan peramalan selanjutnya menggunakan metode MRP dengan proses netting, lotting, offsetting dan exsplosion. Setelah melakukan perhitungan menggunakan metode MRP dengan 4 proses maka dapat diketahui waktu yang tepat dalam melakukan safety stock untuk kelancaran proses produksi bak mobil truk (bak siluman) pada periode selanjutnya yaitu pada bulan ke 12 .
\end{abstract}

Kata kunci : Bak Mobil Truk, Peramalan, MRP, dan Safety Stock

Abstract : CV. Lursa Abadi is a company that produces truck tailgate. Problems that occur in the $C V$. Lursa Abadi is a limited supply of raw materials that occur due to not having a storage warehouse, so this company must order raw materials in advance to suppliers and orders are still done manually which can cause the production process time to be reduced. Therefore this research will be carried out planning raw material inventory using the material requirements planning method in the production process. The purpose of this study is u to know the planning of raw material requirements in the production process of making a truck car and to know the time the company can do safety stock for the smooth production process. The results of this study indicate that the calculation of inventory forecasting using the selected method is a linear method with the smallest SEE value of 0.662 with a total production plan in the 13th period is 7 units. After making the next forecast using the MRP method with the process of netting, lotting, offsetting and exsplosion. After calculating using the MRP method with 4 processes, it can be seen the right time in conducting safety stock for the smooth production process like a truck car (stealth tub) in the next period, namely in the 12th month.

Keywords: Truck Body, Forecasting, MRP, and Safety Stock

\section{PENDAHULUAN}

Perkembangan teknologi pada masa sekarang ini semakin pesat, khususnya pada bidang industri. Seiring dengan kemajuan tersebut perusahaan perusahaan berusaha untuk dapat menghasilkan produk dengan optimal. Namun pemanfaatan kemajuan teknologi mesti memikirkan sumber daya yang ada. Perusahaan juga harus memperhatikan langkah yang diambil dalam menjalankan kegiatannya. 
Proses produksi merupakan kegiatan inti dari suatu perusahaan manufaktur, suatu perusahaan dituntut untuk menghasilkan suatu produk berkualitas sesuai dengan keinginan konsumen. Faktor penting harus diperhatikan adalah penyediaan bahan baku pada proses produksi akan berjalan dengan baik jika persediaan bahan baku seimbang dengan kapasitas persediaan bahan baku seimbang dengan kapasitas produksi perusahaan. Dalam arti persediaan tersebut tidak kurang dan tidak lebih selama proses produksi berlangsung.

Persediaan bahan baku yang tidak seimbang justru dapat menimbulkan masalah yang berpotensi kepada pemutusan pemesanan dari pada pihak pelanggan karena pihak manufaktur tidak bisa menyanggupi jumlah dan tanggal permintaan. Sebaliknya jika persediaan bahan baku yang berlebih justru akan menimbulkan biaya atau cost bagi perusahaan itu sendiri, dengan kondisi tersebut sangat mengganggu kondisi keuangan atau cash flow dari perusahaan.

CV. Lursa Abadi merupakan suatu perusahaan yang memproduksi bak mobil truk. Jenis bak mobil truk yang diproduksi di CV. Lursa Abadi terdiri dari 4 jenis bak yaitu bak siluman, bak sampang, bak petak dan bak mati. Setiap jenis bak mobil truk tersebut menggunakan jenis besi yang sama tapi dengan ukuran yang berbeda beda atau sesuai dengan permintaan dari konsumen. Bak mobil truk yang sering di produksi yang sesuai dengan permintaan konsumen adalah jenis bak siluman.

Permasalahan yang menjadi kendala di perusahaan ini adalah terbatasnya persediaan bahan baku yang terjadi dikarenakan tidak memiliki gudang penyimpanan, sehingga perusahaan ini harus memesan bahan baku terlebih dahulu kepada supplier dan pemesanannya masih dilakukan secara manual sehingga dapat menyebabkan waktu proses produksi menjadi terhambat.

Perencanaan kebutuhan material (material reguirement planning, MRP) merupakan adalah suatu konsep dalam manajemen produksi yang membahas bagaimana cara yang tepat dalam perencanaan dalam kebutuhan barang dalam proses produksi, sehingga barang yang dibutuhkan dapat tersedia sesuai dengan yang direncanakan.

Adapun struktur produk dari pembuatan bak mobil truk (bak siluman) tersebut bisa dilihat pada gambar berikut :

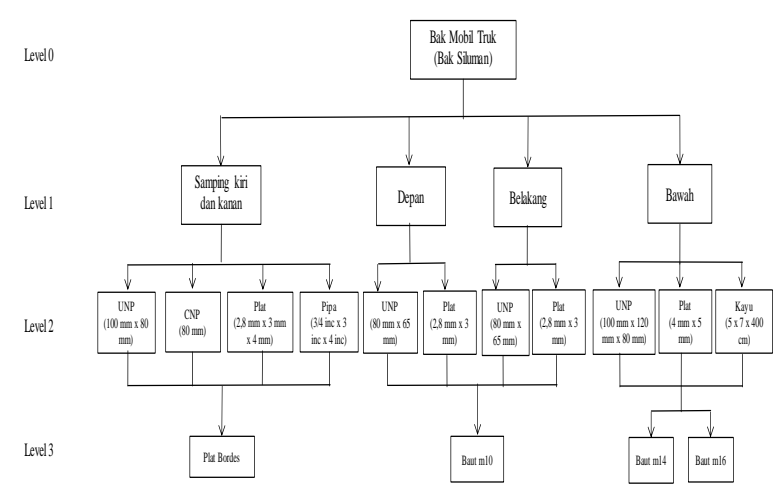

Gambar 1 Struktur Produk Bak Siluman

\section{TINJAUAN PUSTAKA}

Perencanaan produksi adalah kegiatan untuk mendapatkan produk sesuai dengan yang ditetapkan, berkaitan dengan penentuan berapa banyak yang diproduksi, sumber daya apa yang dibutuhkan dan kapan harus diproduksi (Khairani, 2013). Fungsi dan tujuan perencanaan produksi yaitu merencanakan dan mengendalikan aliran material di dalam dan diluar pabrik, dengan demikian keuntungan optimal yang merupakan tujuan perusahaan dapat dicapai.

Persediaan adalah barang - barang yang disimpan untuk digunakan atau dijual pada masa yang akan datang (Ristono, 2009 :2). Persediaan umumnya merupakan salah satu jenis aktiva lancar yang 
jumlahnya cukup besar dalam suatu perusahaan (Sartono, 2009 : 135).

Menurut Ristono (2009) tujuan persediaan dibagi menjadi tiga jenis yaitu :

1. Persediaan pengaman (safety stock). Merupakan persediaan yang untuk mengantisipasi ketidakpastian permintaan dalam penyediaan.

2. Persediaan antisipasi (stabilization stock).

Yaitu persediaan yang dilakukan untuk menghadapi fluktuasi permintaan yang telah dapat diperkirakan sebelumnya.

3. Persediaan dalam pengiriman (transit stock / work in process).

Adalah persediaan masih dalam pengiriman. Persediaan ini terdiri dari dua kelompok, yaitu :

a. Eksternal transit stock adalah persediaan berada dalam transportasi.

b. Internal transit stock merupakan persediaan yang masih menunggu untuk diproses dan menunggu untuk dipindahkan.

Peramalan adalah meramalkan sesuatu yang akan datang dengan berdasarkan data masa lampau. Dalam menganalisanya secara ilmiah. khususnya menggunakan metode statistika (Supranto, 1984).

Hasil peramalan tersebut mempunyai kecenderungan memiliki kesalahan kesalahan. Besarnya kesalahan pada periode $\mathrm{ke}-\mathrm{i}\left(\mathrm{e}_{\mathrm{i}}\right)$ dinyatakan sebagai :

$\mathrm{e}_{\mathrm{i}}=$ kesalahan pada periode $\mathrm{ke}-\mathrm{i}$

$\mathrm{X}_{\mathrm{i}}=$ data aktual periode $\mathrm{ke}-\mathrm{i}$

$\mathrm{F}_{\mathrm{i}}=$ nilai peramalan $\mathrm{ke}-\mathrm{i}$

Beberapa statistik ukuran kesalahan yang biasa dipakai :

1. Mean Error $=\frac{\sum(e i)}{n}$

2. Mean Absolut Error $=\frac{\sum(|e i|)}{n}$

3. Sum of Square Error $=\sum(e i)^{2}$

4. Mean Square Error $=\frac{\sum(e i) 2}{n}$
5. Standard Deviation of Error

$$
=\left(\frac{\sum(e i) 2}{(n-1)}\right)^{1 / 2}
$$

6. Percentage of Error

$$
=\frac{e i}{X i} \times 100 \%
$$

7. Mean Percentage Error

$$
=\frac{\sum(P E i)}{n}
$$

8. Mean Absolute Percentage Error $=\sum \frac{(|P E i|)}{n}$

9. Standard Error of Estimate =

$$
\sqrt{\frac{\sum_{t=1}^{N}(X i-F i)^{2}}{(n-f)}}
$$

Metode MRP merupakan metode perencanaan dan pengendalian pesanan dari persediaan yang memanfaatkan informasi tentang permintaan untuk memanajemeni persediaan dengan pengendalian ukuran lot produksi dari berbagai komponen atau item - item dependent demand yang diperlukan untuk membuat suatu produk akhir.

Salah satu alasan kenapa MRP digunakan secara cepat dan meluas sebagai teknik manajemen produksi, terutama dalam lingkungan manufaktur adalah karena MRP menggunakan komponen komputer untuk menyimpan dan mengolah data yang berguna dalam menjalankan kegiatan perusahaan.

\section{METODE PENELITIAN}

Jenis penelitian yang dilakukan penulis adalah penelitian deskriptif kuantitatif yaitu pengolahan data yang berupa angka pada suatu perusahaan atau industri yang nantinya data akan dikumpulkan dan diolah sehingga memberikan informasi yang berguna dengan menggunakan perumusan matematika (Moh. Nazir; 2015).

Teknik Pengolahan dan Analisis Data adalah sebagai berikut :

1. Mengetahui perencanaan kebutuhan bahan baku dalam proses produksi pembuatan bak mobil truk 
a. Peramalan

Peramalan merupakan prediksi, proyeksi atau estimasi tingkat kejadian yang tidak pasti dimasa yang akan datang, metode peramalan adalah untuk mengetahui SEE (Standard Error of Estimate). Setelah melalui proses peramalan maka akan didapatkan MPS atau jadwal induk produksi untuk periode selanjutnya.

b. MPS (Master Production Schedule) yaitu jadwal induk produksi jadi untuk periode mendatang yang dirancang berdasarkan ramalan permintaan.

c. MRP (Material Requirement Planning) Merupakan konsep dalam manajemen produksi membahas cara yang tepat dalam menentukan perencanaan kebutuhan barang dalam proses produksi, sehingga barang yang dibutuhkan dapat tersedia sesuai dengan yang direncanakan.

2. Untuk Kelancaran Proses Produksi Perusahaan dapat.melakukan Safety Stock dengan langkah-langkah berikut ini :

a. Perhitungan Kebutuhan Bersih (Netting) adalah perhitungan yang menetapkan..kebutuhan bersih yang merupakan selisih antara kebutuhan kotor dengan keadaan persediaan.

b. Menentukan Ukuran Lot (Lotting) adalah proses menentukan besarnya permintaan setiap item berdasarkan kebutuhan bersih yang dihasilkan pada proses netting.

c. Proses Offsetting yaitu penentuan waktu yang tepat untuk melakukan perencanaan pemesanan dalam memenuhi tingkat kebutuhan bersih.

d. Proses explosion ini merupakan data struktur produk untuk menentukan arah explosion item komponen.
Dalam penelitian ini data diambil dari data sekunder yang berdasarkan informasi yang didapat dari CV. Lursa Abadi yang berkaitan dengan pemecahan pada penelitian ini yaitu :

1. Data pemesanan produksi bak mobil truk periode sebelumnya..

2. Data persediaan bahan baku.

3. Struktur Produk.

4. Data lead time setiap komponen..

Adapun tempat penelitian yang dilakukan adalah di CV. Lursa Abadi yang beralamat di jln. raya by pass $\mathrm{Km}$. 6, Lubuk Begalung Nan XX, Kec. Lubuk Begalung, Kota Padang, Sumatera Barat. Penelitian ini dilakukan pada bulan Mei 2020.

\section{HASIL DAN PEMBAHASAN}

Langkah awal melakukan perhitungan dalam membuat perencanaan dalam proses produksi bak mobil truk (bak siluman) adalah menggunakan metode peramalan pada permintaan produk bak siluman di CV. Lursa Abadi, metode peramalan yang digunakan yaitu peramalan yang mempunyai nilai SEE (Standard Error Of Estimate) terkecil.

Berikut data persediaan bahan baku :

Tabel 1 Data Persediaan Bahan Baku

\begin{tabular}{|c|l|c|c|c|}
\hline No & Nama Komponen & Level & Inventory & Satuan Bahan Baku \\
\hline 1 & Besi Plat & 2 & 3 & Lembar \\
\hline 2 & Besi UNP & 2 & 6 & Batang \\
\hline 3 & Besi CNP & 2 & 6 & Batang \\
\hline 4 & Besi Pipa & 2 & 3 & Batang \\
\hline 5 & Kayu & 2 & 2 & Batang \\
\hline 6 & Plat bordes & 3 & 2 & Lembar \\
\hline 7 & Baut m10 & 3 & 4 & Buah \\
\hline 8 & Baut m14 & 3 & 4 & Buah \\
\hline 9 & Baut m16 & 3 & 6 & Buah \\
\hline
\end{tabular}

Sumber : CV. Lursa Abadi

Berikut adalah peramalan bak siluman yang dilakukan pada CV. Lursa Abadi dengan menggunakan tiga metode peramalan yang dapat dilihat pada tabel tabel di bawah ini : 
1. Menggunakan metode peramalan linear dapat dilihat pada tabel berikut dengan fungsi peramalan $y^{\prime}=a+b t$ :

Tabel 2 Metode Peramalan Linier

\begin{tabular}{|c|c|c|c|c|c|}
\hline Periode & $\mathbf{t}$ & $\mathbf{t}^{\mathbf{2}}$ & $\mathbf{y}$ & $\mathbf{t y}$ & $\mathbf{y}^{\mathbf{\prime}}$ \\
\hline 1 & 1 & 1 & 6 & 6 & 6,4558 \\
\hline 2 & 2 & 4 & 10 & 20 & 6,4941 \\
\hline 3 & 3 & 9 & 8 & 24 & 6,5324 \\
\hline 4 & 4 & 16 & 6 & 24 & 6,5708 \\
\hline 5 & 5 & 25 & 5 & 25 & 6,6091 \\
\hline 6 & 6 & 36 & 4 & 24 & 6,6475 \\
\hline 7 & 7 & 49 & 6 & 42 & 6,6858 \\
\hline 8 & 8 & 64 & 7 & 56 & 6,7242 \\
\hline 9 & 9 & 81 & 6 & 54 & 6,7625 \\
\hline 10 & 10 & 100 & 8 & 80 & 6,8009 \\
\hline 11 & 11 & 121 & 8 & 88 & 6,8392 \\
\hline 12 & 12 & 144 & 6 & 72 & 6,8776 \\
\hline TOTAL & 78 & 650 & 80 & 515 & 80 \\
\hline
\end{tabular}

sumber : pengolahan data

Kemudian untuk menghitung rata - rata kuadrat kesalahan (Standard Error Of Estimate) pada peramalan linear yaitu dengan rumus berikut ini :

$$
S E E=\sqrt{\frac{\sum\left(y-y^{\prime}\right) 2}{n-f}}
$$

Keterangan : $\Sigma=$ Total keseluruhan

$$
\begin{aligned}
& \text { y = Data permintaan } \\
& \text { y'= Hasil penjumlahan akhir } \\
& \text { n = Jumlah periode } \\
& \text { f = Derajat kebebasan }
\end{aligned}
$$

Berikut dapat dilihat pada tabel

\begin{tabular}{|c|c|c|c|c|}
\hline Periode & $\mathbf{y}$ & $\mathbf{y}^{\prime}$ & $e=y-y^{\prime}$ & $\mathbf{e}^{2}$ \\
\hline 1 & 6 & 6,4558 & $-0,4558$ & 0,20771 \\
\hline 2 & 10 & 6,4941 & 3,5059 & 12,2913 \\
\hline 3 & 8 & 6,5324 & 1,4676 & 2,15371 \\
\hline 4 & 6 & 6,5708 & $-0,5708$ & 0,32581 \\
\hline 5 & 5 & 6,6091 & $-1,6091$ & 2,58935 \\
\hline 6 & 4 & 6,6475 & $-2,6475$ & 7,00922 \\
\hline 7 & 6 & 6,6858 & $-0,6858$ & 0,47038 \\
\hline 8 & 7 & 6,7242 & 0,2758 & 0,07607 \\
\hline 9 & 6 & 6,7625 & $-0,7625$ & 0,58146 \\
\hline 10 & 8 & 6,8009 & 1,1991 & 1,43788 \\
\hline 11 & 8 & 6,8392 & 1,1608 & 1,34738 \\
\hline 12 & 6 & 6,8776 & $-0,8776$ & 0,77015 \\
\hline \multicolumn{4}{|c|}{ Jumlah } & 29,2604 \\
\hline \multicolumn{4}{|c|}{ SEE } & 0,6621 \\
\hline
\end{tabular}
perhitungan SEE metode linear untuk mendapatkan hasil peramalan yaitu :

Tabel 3 Perhitungan SEE Metode Peramalan Linear

Sumber : Pengolahan Data
2. Menggunakan metode peramalan kuadratis dapat dilihat pada tabel di bawah ini dengan fungsi peramalan y' = $a+b t+c t^{2}$ :

Tabel 4 Metode Peramalan Kuadratis

\begin{tabular}{|c|c|c|c|c|c|c|c|c|}
\hline Periode & $\mathrm{t}$ & $\mathrm{t}^{2}$ & $\mathrm{t}^{3}$ & $\mathrm{t}^{4}$ & $\mathrm{y}$ & $\mathrm{yt}$ & $\mathrm{t}^{2} \mathrm{y}$ & $\mathrm{y}^{\prime}$ \\
\hline 1 & 1 & 1 & 1 & 1 & 6 & 6 & 6 & -125.730 .976 \\
\hline 2 & 2 & 4 & 8 & 16 & 10 & 20 & 40 & -102.870 .755 \\
\hline 3 & 3 & 9 & 27 & 81 & 8 & 24 & 72 & -80.010 .547 \\
\hline 4 & 4 & 16 & 64 & 256 & 6 & 24 & 96 & -57.150 .351 \\
\hline 5 & 5 & 25 & 125 & 625 & 5 & 25 & 125 & -34.290 .168 \\
\hline 6 & 6 & 36 & 216 & 1.296 & 4 & 24 & 144 & -11.429 .998 \\
\hline 7 & 7 & 49 & 343 & 2.401 & 6 & 42 & 294 & 11.4330 .159 \\
\hline 8 & 8 & 64 & 512 & 4.096 & 7 & 56 & 448 & 34.290 .304 \\
\hline 9 & 9 & 81 & 729 & 6.561 & 6 & 54 & 486 & 57.150 .436 \\
\hline 10 & 10 & 100 & 1.000 & 10.000 & 8 & 80 & 800 & 80.010 .556 \\
\hline 11 & 11 & 121 & 1.331 & 14.641 & 8 & 88 & 968 & 102.870 .662 \\
\hline 12 & 12 & 144 & 1.728 & 20.736 & 6 & 72 & 864 & 125.730 .756 \\
\hline T0TAL & 78 & 650 & 6.084 & 60.710 & 80 & 515 & 4.343 & 80 \\
\hline
\end{tabular}

Sumber: Pengolahan Data

Dari pengolahan data peramalan permintaan produk bak mobil truk (bak

\begin{tabular}{|c|c|c|c|c|}
\hline Periode & $\mathrm{y}$ & $y^{\prime}$ & $e=y-y^{\prime}$ & $e^{2}$ \\
\hline 1 & 6 & -125.730 .976 & 125.730 .982 & 15.808.279.761.292.400 \\
\hline 2 & 10 & -102.870 .755 & 102.870 .765 & 10.582 .394 .242 .084 .700 \\
\hline 3 & 8 & -80.010 .547 & 80.010 .555 & 6.401.688.833.058.970 \\
\hline 4 & 6 & -57.150 .351 & 57.150 .357 & 3.266 .163 .300 .945 .050 \\
\hline 5 & 5 & -34.290 .168 & 34.290 .173 & 1.175 .815 .972 .282 .100 \\
\hline 6 & 4 & -11.429 .998 & 11.430 .002 & 130.644 .945 .008 .915 \\
\hline 7 & 6 & 11.430 .159 & -11.430 .153 & 130.648 .408 .505 .427 \\
\hline 8 & 7 & 34.290 .304 & -34.290 .297 & 1.175 .824 .483 .573 .260 \\
\hline 9 & 6 & 57.150 .436 & $\begin{array}{l}-57.150 .430 \\
\end{array}$ & 3.266 .171 .679 .637 .090 \\
\hline 10 & 8 & 80.010 .556 & -80.010 .548 & 6.401 .687 .728 .876 .770 \\
\hline 11 & 8 & 102.870 .662 & -102.870 .654 & 10.582 .371 .506 .481 .700 \\
\hline 12 & 6 & 125.730 .756 & -125.730 .750 & 15.808 .221 .544 .738 .900 \\
\hline \multicolumn{4}{|c|}{ Jumlah } & 74.729 .912 .406 .485 .200 \\
\hline \multicolumn{4}{|c|}{ SEE } & 78.914 .464 \\
\hline
\end{tabular}
siluman) dengan metode kuadratis maka didapat hasil SEE sebagai berikut:

Tabel 5 Perhitungan SEE Metode Peramalan Kuadratis

Sumber : Pengolahan Data 
3. Menggunakan metode peramalan siklis dapat dilihat pada tabel di bawah ini dengan fungsi peramalan $y^{\prime}=a+b \sin$ $\left(\frac{2 \pi t}{n}\right)+c \cos \left(\frac{2 \pi t}{n}\right)$ :

Tabel 6 Metode Peramalan Siklis

\begin{tabular}{|c|c|c|c|c|c|c|c|c|c|c|}
\hline Periode & t & I & $\sin \frac{2 \pi}{11}$ & $\cos \frac{2 \pi}{n}$ & $\sin \frac{2 \pi}{\pi}$ & $y \cos \frac{2 \pi}{n}$ & $\sin ^{2} \frac{2 \pi}{n}$ & $\cos ^{2} \frac{2 \pi}{n}$ & $\sin \frac{2 \pi}{n} \cos \frac{2 \pi}{\pi}$ & $y^{\prime}$ \\
\hline 1 & & & 50 & 0,87 & 2,9986 & 5,1960 & 0,25 & 0,75 & 0,4329 & 7,544 \\
\hline 2 & & & 0,87 & 0,00 & 8,6576 & 5,0046 & 0,75 & 0,25 & 01232 & 7,8048 \\
\hline 3 & & & 1,00 & 0,00 & 8,0000 & 0,0064 & 1,00 & 0,00 & 0,0000 & 7,8506 \\
\hline 4 & 1 & & 0,87 & $.0,50$ & 5,1993 & $-2,9945$ & 0,75 & 0,25 & 50235 & 7,5798 \\
\hline$j$ & & & 0,50 & $.0,87$ & 2,5057 & $-4,3268$ & 0,25 & 0,75 & $\cdot-0,4337$ & 7,0646 \\
\hline 6 & 6 & & 0,00 & $\cdot 1,00$ & 0,0064 & $-4,0000$ & 0,00 & 1,00 & $-0,0016$ & 6,431 \\
\hline 7 & 1 & & $.0,50$ & $.0,87$ & $-2,9903$ & $-5,2017$ & 0,55 & 0,75 & $0,7 J 121$ & 5,8816 \\
\hline 8 & $\gamma$ & & $-0,86$ & 0 & $-6,0,547$ & $-3,5120$ & 0,75 & 0,25 & 0,4341 & 5,5304 \\
\hline 9 & $y^{\prime}$ & & $\cdot 1,00$ & 0,00 & $.6,0000$ & $-0,0143$ & 1,00 & 0,00 & 0,0024 & 5,4836 \\
\hline 10 & 10 & 0 & $\cdot 0,87$ & 0,00 & $.6,9388$ & 3,9816 & 0,75 & 0,25 & $\cdot 0,4317$ & 5,7536 \\
\hline 11 & 11 & & $-0,50$ & 0,86 & $-4,0202$ & 6,9165 & 0,25 & 0,75 & $-0,4345$ & 6,2681 \\
\hline 12 & 12 & 0 & 0,00 & 1,00 & $-0,1191$ & 6,0000 & 0,00 & 1,00 & $-0,0032$ & 6,8896 \\
\hline Total & 78 & 8 & 0,00 & $\begin{array}{r}-0,01 \\
\end{array}$ & 1,345 & 7,0558 & 6,00 & 6,00 & $.0,0016$ & 8000021 \\
\hline
\end{tabular}

Sumber : Pengolahan Data

Dari pengolahan data peramalan permintaan produk bak mobil truk (bak siluman) dengan metode siklis maka didapat hasil SEE sebagai berikut :

Tabel 7 Perhitungan SEE Metode Peramalan Siklis

\begin{tabular}{|c|c|c|c|c|}
\hline $\mathbf{t}$ & $\mathbf{y}$ & $\mathbf{y}^{\prime}$ & $\mathbf{e}=\mathbf{y}-\mathbf{y}^{\prime}$ & $\mathbf{e}^{\mathbf{2}}$ \\
\hline 1 & 6 & 7,4544 & $-1,4544$ & 2,1153 \\
\hline 2 & 10 & 7,8048 & 2,1952 & 4,8191 \\
\hline 3 & 8 & 7,8506 & 0,1494 & 0,0223 \\
\hline 4 & 6 & 7,5798 & $-1,5798$ & 2,4956 \\
\hline 5 & 5 & 7,0646 & $-2,0646$ & 4,2626 \\
\hline 6 & 4 & 6,4431 & $-2,4431$ & 5,9688 \\
\hline 7 & 6 & 5,8816 & 0,1184 & 0,0140 \\
\hline 8 & 7 & 5,5304 & 1,4696 & 2,1596 \\
\hline 9 & 6 & 5,4836 & 0,5164 & 0,2667 \\
\hline 10 & 8 & 5,7536 & 2,2464 & 5,0465 \\
\hline 11 & 8 & 6,2681 & 1,7319 & 2,9993 \\
\hline 12 & 6 & 6,8896 & $-0,8896$ & 0,7913 \\
\hline \multicolumn{5}{|c|}{ Jumlah } \\
\hline
\end{tabular}

Sumber: Pengolahan Data

Metode peramalan yang dipilih yaitu metode peramalan yang mempunyai nilai SEE terkecil. Berikut rekap nilai SEE terkecil dari tiga metode peramalan yang digunakan yaitu sebagai berikut :

Tabel 8 Rekapitulasi SEE Metode Peramalan

\begin{tabular}{|c|c|c|c|}
\hline No & Metode & SEE & SEE terkecil \\
\hline 1 & Linear & 0,6621 & \multirow{3}{*}{0,6621} \\
\hline 2 & Kuadratis & 78.914 .464 & \\
\hline 3 & Siklis & 0,7616 & \\
\hline
\end{tabular}

Sumber:Pengolahan Data

Dari tabel di atas dapat dilihat nilai SEE terkecil adalah metode linear dengan nilai SEE yaitu 0,6621 , sedangkan nilai SEE terbesar adalah metode kuadratis dengan nilai 78.914.464. Maka untuk melakukan perhitungan peramalan persediaan bahan baku selanjutnya akan digunakan hasil peramalan metode linear karena metode ini memiliki nilai SEE terkecil dengan fungsi peramalan yaitu y'=a + bt.

Untuk peramalan produksi periode 13 s/d 24 dapat dilihat pada tabel berikut ini :

Tabel 9 Hasil Peramalan Bak Siluman

\begin{tabular}{|c|c|c|}
\hline No & Periode & Ramalan Produksi (Unit) \\
\hline 1 & 13 & 7 \\
\hline 2 & 14 & 7 \\
\hline 3 & 15 & 7 \\
\hline 4 & 16 & 8 \\
\hline 5 & 17 & 8 \\
\hline 6 & 18 & 8 \\
\hline 7 & 19 & 8 \\
\hline 8 & 20 & 8 \\
\hline 9 & 21 & 8 \\
\hline 10 & 22 & 8 \\
\hline 11 & 23 & 8 \\
\hline 12 & 24 & 8 \\
\hline \multicolumn{2}{|c|}{ TOTAL } & 93 \\
\hline
\end{tabular}

Sumber: Pengolahan Data

Maka MPS atau jadwal induk produksi untuk bak mobil truk (bak siluman) pada CV. Lursa Abadi dapat dilihat pada tabel di bawah ini :

Tabel 10 Jadwal Induk Produksi Periode 13 s/d 24

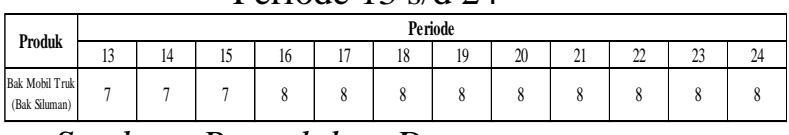

Sumber: Pengolahan Data 
Setelah menentukan metode peramalan dan jadwal induk produksi (MPS), langkah selanjutnya yaitu melakukan proses MRP (Material Requirement Planning) dengan proses awal yang dilakukan pada MRP yaitu proses netting atau kebutuhan bersih dari masing - masing komponen bahan baku, kebutuhan bersih dihitung berdasarkan struktur produk yang ada. Proses yang kedua yaitu proses lotting atau penentuan besarnya pesanan yang optimal berdasarkan hasil perhitungan kebutuhan bersih. Proses yang ketiga yaitu proses offsetting atau penentuan waktu yang tepat untuk melakukan perencanaan kebutuhan bahan baku. Proses yang terakhir yaitu proses explosion atau perhitungan kebutuhan kotor dari setiap komponen bahan baku pembuatan bak siluman.

Berikut ini adalah proses netting atau perhitungan kebutuhan bersih dan perencanaan kebutuhan bahan baku untuk komponen bak siluman yang dapat dilihat pada tabel di bawah ini :

Tabel 11 Perhitungan Kebutuhan Bersih (Netting) Bak Siluman

\begin{tabular}{|c|c|c|c|c|c|c|c|c|c|c|c|c|c|c|}
\hline 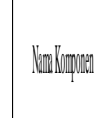 & It & & & manne. & & v & & 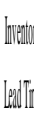 & & 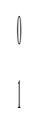 & & & & \\
\hline Panter & $\|$ & L. & B & It & if & 16 & & $\mathbb{1}$ & i) & d) & & 1 & $B$ & $y$ \\
\hline (ritatimation & & & 1 & 1 & t & 8 & 8 & 8 & 8 & f & & 8 & & 1 \\
\hline Pratimituman & 1 & 1 & . & 1 & 1 & 1 & 1 & 1 & 1 & 1 & & 1 & 1 & 1 \\
\hline 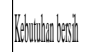 & & & 1 & 1 & 1 & 8 & 8 & 8 & 8 & 8 & & 8 & & 8 \\
\hline
\end{tabular}

Sumber: Pengolahan Data

Proses Netting adalah proses perhitungan untuk menetapkan kebutuhan bersih yang merupakan selisih antara kebutuhan kotor dengan keadaan persediaan ditangan. Dari tabel diatas maka kebutuhan bersih yang didapat untuk bak siluman periode ke 13 adalah 7 unit.
Berikut ini adalah penentuan besarnya pesanan yang optimal untuk kebutuhan bahan baku bak siluman yang terdapat pada tabel di bawah ini :

Tabel 12 Perhitungan Pesanan Optimal (Lotting) Bak Siluman

\begin{tabular}{|c|c|c|c|c|c|c|c|c|c|c|c|c|c|c|}
\hline \multirow{2}{*}{ Kama Komponen: } & \multirow{2}{*}{\multicolumn{2}{|c|}{$\begin{array}{c}\text { Bal } \\
\text { Silmanan }\end{array}$}} & \multicolumn{3}{|c|}{ Lerel: } & \multicolumn{2}{|c|}{0} & \multicolumn{2}{|c|}{ livethoy: } & \multicolumn{2}{|c|}{0} & & & \\
\hline & & & & maporenen & & . & & & & & & & & \\
\hline Pendide & 11 & 12 & B & H & 15 & 16 & 17 & 18 & 19 & n & 21 & 2 & 23 & It \\
\hline 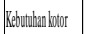 & & & 7 & 7 & 7 & 8 & 8 & 8 & 8 & 8 & 8 & 8 & 8 & 8 \\
\hline 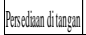 & 0 & 0 & 7 & 0 & 0 & 0 & 0 & 0 & 0 & 0 & 0 & 0 & 0 & 0 \\
\hline Kebtuthan berin & & & $?$ & 1 & 1 & 8 & 8 & 8 & 8 & 8 & 8 & 8 & 8 & 8 \\
\hline 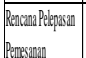 & & 1 & 1 & 1 & 8 & 8 & 8 & 8 & 8 & 8 & 8 & 8 & 8 & \\
\hline
\end{tabular}

Sumber: Pengolahan Data

Proses Lotting adalah proses penentuan ukuran pemesanan untuk memenuhi kebutuhan bersih untuk satu atau beberapa periode sekaligus sehingga dapat meminimalkan persediaan yang dikurangi dengan lead time. Dari tabel diatas maka pesanan optimal untuk periode ke-13 memiliki kekurangan yaitu sebesar -7 unit yang dikurangi dengan besarnya lead time $=1$.

Berikut adalah pengolahan data untuk penentuan waktu yang tepat dalam melakukan proses produksi bak siluman yang dapat dilihat pada tabel di bawah ini :

Tabel 13 Perhitungan Perencanaan

Produksi (Offsetting) Bak Siluman

\begin{tabular}{|c|c|c|c|c|c|c|c|c|c|c|c|c|c|c|}
\hline \multirow{2}{*}{ Nam Konponen: } & \multirow{2}{*}{\multicolumn{2}{|c|}{$\begin{array}{c}\text { Bak } \\
\text { Siluman }\end{array}$}} & \multicolumn{3}{|c|}{ Level: } & \multicolumn{2}{|c|}{0} & \multicolumn{2}{|c|}{ Inventory: } & \multicolumn{2}{|c|}{0} & & & \\
\hline & & & & mponen & & & & & & & & & & \\
\hline Periode & 11 & 12 & B & 14 & 15 & 16 & 17 & 18 & 19 & 20 & 21 & 2 & 23 & 24 \\
\hline Kebutuhan lootor & & & 1 & $?$ & 7 & 8 & 8 & 8 & 8 & 8 & 8 & 8 & 8 & 8 \\
\hline Kebutuhan berih & & & 7 & 7 & 7 & 8 & 8 & 8 & 8 & 8 & 8 & 8 & 8 & 8 \\
\hline 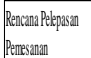 & & 7 & 7 & 1 & 8 & 8 & 8 & 8 & 8 & 8 & 8 & 8 & 8 & \\
\hline
\end{tabular}

Sumber: Pengolahan Data

Proses Offsetting adalah proses untuk menentukan saat yang tepat dalam melakukan rencana pelepasan pemesanan untuk memenuhi kebutuhan bersih (netting). Dari tabel diatas rencana pelepasan pemesana di mulai pada periode ke 12 dengan jumlah 7 unit. 
Berikut adalah perhitungan kebutuhan kotor untuk komponen bak siluman yang dapat dilihat pada tabel di bawah ini :

Tabel 14 Perhitungan Kebutuhan Kotor (Explosion) Bak Siluman

\begin{tabular}{|c|c|c|c|c|c|c|c|c|c|c|c|c|c|c|}
\hline lang Korponan: & \multicolumn{2}{|c|}{$\begin{array}{l}\text { Buk } \\
\text { Shirmon }\end{array}$} & \multicolumn{3}{|c|}{ Lerel: } & \multicolumn{2}{|c|}{0} & \multicolumn{2}{|c|}{ 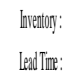 } & 0 & & & & \\
\hline Prinde & $\|$ & 12 & $B$ & H & 15 & 16 & 17 & 18 & 19 & n & 21 & 2 & $B$ & 24 \\
\hline 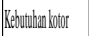 & & 1 & 1 & 1 & 8 & 8 & 8 & 8 & 8 & 8 & 8 & 8 & 8 & \\
\hline Persediananditangana & & & & & & & & & & & & & & \\
\hline 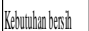 & & & & & & & & & & & & & & \\
\hline
\end{tabular}

Sumber: Pengolahan Data

Proses explosion adalah perhitungan kebutuhan kotor untuk komponen berikutnya, yang didapat dari rencana produksi pada proses offsetting yang mana kebutuhan kotornya dimulai pada periode ke 12.

Kesimpulan yang didapat dari proses proses diatas adalah dimana proses netting untuk bak siluman pada periode ke 13 adalah 7 unit, karena jumlah persediaan produknya 0 dengan jumlah permintaan 7 unit.

Berikut adalah rekapitulasi proses proses MRP dari masing - masing komponen yang dapat dilihat pada tabel di bawah ini :

Tabel 15 Rekapitulasi Proses MRP

\begin{tabular}{|c|c|c|c|c|c|c|c|}
\hline \multirow{2}{*}{ No } & \multirow{2}{*}{$\begin{array}{c}\text { Nama } \\
\text { Komponen }\end{array}$} & \multirow{2}{*}{ Inventory } & \multicolumn{4}{|c|}{ Proses MRP } & \multirow{2}{*}{$\begin{array}{c}\text { Satuan } \\
\text { Bahan Baku }\end{array}$} \\
\hline & & & Netting & Lotting & Offsetting & Explosion & \\
\hline 1 & Bak Siluman & 0 & 7 & -7 & 7 & 7 & Unit \\
\hline 2 & Besi Plat & 3 & 4 & -4 & 4 & 4 & Lembar \\
\hline 3 & BesiUNP & 6 & 1 & -1 & 1 & 1 & Batang \\
\hline 4 & BesiCNP & 6 & 1 & -1 & 1 & 1 & Batang \\
\hline 5 & Besi Pipa & 3 & 4 & -4 & 4 & 4 & Batang \\
\hline 6 & Kayu & 2 & 5 & -5 & 5 & 5 & Batang \\
\hline 7 & Plat bordes & 2 & 5 & -5 & 5 & 5 & Lembar \\
\hline 8 & Baut ml0 & 4 & 3 & -3 & 3 & 3 & Buah \\
\hline 9 & Baut $\mathrm{ml} 4$ & 4 & 3 & -3 & 3 & 3 & Buah \\
\hline 10 & Baut M16 & 6 & 1 & -1 & 1 & 1 & Buah \\
\hline
\end{tabular}

Sumber: Pengolahan Data

Dari tabel di atas dapat dilihat bahwa komponen bak siluman dengan proses netting $=7$, proses lotting $=-7$, proses offsetting $=7$ dan proses explosion $=7$ karena inventory yang dimiliki adalah 0 dengan jumlah permintaan 7 unit.
Untuk komponen besi plat dengan proses netting $=4$, proses lotting $=-4$, proses offsetting $=4$ dan proses explosion $=4$ karena inventory yang dimiliki adalah 3 lembar. Untuk komponen besi UNP dan besi CNP dengan masing - masing proses netting $=1$, proses lotting $=-1$, proses offsetting $=1$ dan proses explosion $=1$ karena inventory yang dimiliki adalah 6 batang.

Untuk komponen besi pipa dengan proses netting $=4$, proses lotting $=-4$, proses offsetting $=4$ dan proses explosion $=4$ karena inventory yang dimiliki adalah 3 batang. Untuk komponen kayu dan plat bordes dengan masing - masing proses netting $=5$, proses lotting $=-5$, proses offsetting $=5$ dan proses explosion $=5$ karena inventory yang dimiliki masing masing adalah 2 .

Untuk komponen baut m10 dan baut m14 dengan masing - masing proses netting $=3$, proses lotting $=-3$, proses offsetting $=3$ dan proses explosion $=3$ karena inventory yang dimiliki masing - masing komponen adalah 4 buah. Dan untuk komponen baut m16 dengan masing - masing proses netting $=1$, proses lotting $=-1$, proses offsetting $=1$ dan proses explosion $=1$ karena inventory yang dimiliki adalah 6 buah.

Setelah melakukan perhitungan menggunakan metode MRP dengan proses netting, lotting, offsetting dan explosion untuk setiap komponen bahan baku dapat diketahui waktu yang tepat dalam melakukan safety stock untuk kelancaran proses produksi bak mobil truk (bak siluman) di CV. Lursa Abadi dapat dilihat pada tabel di bawah ini : 
Tabel 16 Waktu Perencanaan Safety Stock

\begin{tabular}{|c|l|c|c|c|}
\hline No & $\begin{array}{c}\text { Nama } \\
\text { Komponen }\end{array}$ & $\begin{array}{c}\text { Jumlah } \\
\text { Produksi }\end{array}$ & $\begin{array}{c}\text { Satuan Bahan } \\
\text { Baku }\end{array}$ & $\begin{array}{c}\text { Waktu Safety } \\
\text { Stock (Bulan ke-) }\end{array}$ \\
\hline 1 & Bak Siluman & 7 & Unit & 12 \\
\hline 2 & Besi Plat & 4 & Lembar & 12 \\
\hline 3 & Besi UNP & 1 & Batang & 12 \\
\hline 4 & Besi CNP & 1 & Batang & 12 \\
\hline 5 & Besi Pipa & 4 & Batang & 12 \\
\hline 6 & Kayu & 5 & Batang & 12 \\
\hline 7 & Plat bordes & 5 & Lembar & 12 \\
\hline 8 & Baut m10 & 3 & Buah & 12 \\
\hline 9 & Baut m14 & 3 & Buah & 12 \\
\hline 10 & Baut M16 & 1 & Buah & 12 \\
\hline
\end{tabular}

Sumber : Pengolahan Data

Berdasarkan tabel di atas maka waktu perencanaan untuk melakukan safety stock di CV. Lursa Abadi pada periode selanjutnya yaitu pada bulan ke 12 . Dengan adanya safety stock ini perusahaan tidak perlu merasa cemas terhadap ketidak tersediaan bahan baku tersebut sehingga proses produksi tidak terhambat.

\section{KESIMPULAN}

Berdasarkan pengolahan dan pembahasan yang telah dilakukan, maka dapat disimpulkan sebagai berikut :

1. Untuk dapat mengetahui perencanaan kebutuhan bahan baku dalam proses produksi pembuatan bak mobil truk (bak siluman) untuk 12 periode kedepan yaitu dengan langkah awal menggunakan hasil peramalan yang didapatkan dari metode peramalan terpilih dengan nilai SEE terkecil yaitu metode linear dengan nilai SEE sebesar 0,6621. Maka hasil peramalan untuk perencanaan kebutuhan bahan baku periode ke 13, periode ke 14 dan periode ke 15 adalah 7 unit, sedangkan periode ke 16 sampai dengan periode ke 24 adalah 8 unit per bulannyaa. Maka total peramalan untuk 1 tahun kedepan adalah 93 unit.

2. Dapat mengetahui waku yang tepat untuk perusahaan melakukan safety stock dalam kelancaran produksi yaitu pada bulan ke 12 dengan jumlah komponen bahan baku yang diperlukan dalam produksi bak mobil truk (bak siluman) untuk periode ke 13 yaitu besi plat 4 lembar dengan inventori 3 lembar, besi UNP 1 batang dengan inventori 6 batang, besi CNP 1 batang dengan inventori 6 batang, besi pipa 4 batang dengan inventori 3 batang, kayu 5 batang dengan inventori 2 batang, plat bordes 5 lembar dengan inventori 2 lembar, baut $\mathrm{m} 10$ dan baut $\mathrm{m} 14$ berjumlah 3 buah dengan inventori berjumlah 4 buah dan baut m16 1 buah dengan inventori 6 buah.

\section{DAFTAR PUSTAKA}

Alam, Wahyu Purnama. 2019. Perencanaan Persediaan Bahan Baku Wajan Dengan Metode MRP Pada Perusahaan Cor Aluminium Bintang Dua Di Kec. Cikoneng Kab. Ciamis. Jurnal Media Teknologi. Volume 05 Nomor 1.

Anggriana, Zita Katarina. 2015. Perencanaan dan Pengendalian Persediaan Busbar Berdasarkan Sistem MRP. Vol IX No 3, Hal : 320 - 337. Jurnal Teknik Industri, Universitas Mercu Buana Jakarta.

Arbi, Yaumal. 2019. Buku Panduan Penulisan Laporan Kerja Praktik dan Tugas Akhir, Sekolah Tinggi Teknologi Industri Padang, Padang.

Bunga, William Ariel Yosia, \& Rinawati, Dyah Ika. 2019. Perencanaan Persediaan Bahan Baku Semen Dengan Menggunakan Metode Material Requirement Planning (Mrp) Pada PT Indocement Tunggal Prakarsa Tbk. Plant Cirebon. Industrial Engineering Online Journal, Volume 7 Nomor 4.

Gasverz, V. 1998. Production Planning and Inventory Control, PT. Gramedia Pustaka Utama, Jakarta.

Irawan, Putut Ade \& Syaichu, Achmad. 2017. Pengendalian Persediaan Bahan Baku dengan Metode (MRP) Pada PT. 
Semen Indonesia (Persero), Tbk.

Journal Knowledge Industrial

Engineering, Volume 4 Nomor 1.

Khairani, Diana. 2013. Perencanaan Pengendalian Produksi, Graha Ilmu, Yogyakarta.

Kusuma, Hendra. 2008. Perencanaan dan Pengendalian Produksi, Gunawidya, Surabaya.

Riko Ervil, Mela Rosalina. 2019. Estimasi Permintaan Air Minum Dalam Kemasan Ayia Cip 240 ML Pada PT. Gunung Naga Mas, Jurnal Pendidikan Teknologi Kejuruan, Volume 2, Issue 2.

Sari, Dini Hanafi, dan Wiwik Budiawan, ST., MT, 2017. Analisis Penerapan (MRP) dengan Mempertimbangkan Lot Sizing dalam Pengendalian Persediaan Kebutuhan Bahan Baku Xoly Untuk Pembuatan ALKYD 9337. Jurnal Teknik Industri FTUNDIP. Volume 6 Nomor 1.

Abdurahman, Nandar Cundara, Sanusi Sanusi, \& Muh. Wahyu Ar. 2018. Analisa Pengendalian Persediaan Kabel Rg 6 Dengan Menggunakan Metode (MRP) Dan Vendor Managed Inventory (VMI). Jurnal Teknik Ibnu Sina (JT-IBSI), Volume 3 Nomor 1. 